\title{
Keanekaragaman Hama Tanaman Padi dari Ordo Orthoptera pada Ekosistem Sawah di Desa Mantingan Kabupaten Ngawi
}

\author{
Lydia Rosmaretta Gayatri ${ }^{1{ }^{*}}$, Muhammad Nurul ${ }^{2)}$, Fakhrun Nisak ${ }^{3)}$ \\ Program Studi Pendidikan IPA, Fakultas Matematika dan Ilmu Pengetahuan Alam, Universitas Negeri Malang \\ *lydia.rosmaretta.1903516@students.um.ac.id
}

\begin{abstract}
Abstrak: Beragam jenis hama yang hidup di sekitar tanaman padi, salah satunya berasal dari ordo Orthoptera. Tujuan penelitian ini adalah untuk mendeskripsikan jenis-jenis hama tanaman padi dari ordo Orthoptera di Desa Mantingan, Kabupaten Ngawi dan cara yang baik untuk memberantas hama tanpa menimbulkan dampak negatif terhadap lingkungan. Metode dalam penelitian ini adalah pengamatan atau observasi dan studi literatur. Hasil dari penelitian ini, ditemukan tiga spesies hama dari ordo Orthoptera, diantaranya Oxya chinensis (belalang hijau), Gryllotalpa hirsuta (anjing tanah atau orong-orong), dan Atractomorpha crenulata (belalang kukus hijau). Ketiga hama tersebut menyerang tanaman padi dengan cara menggigit dan mengunyah pada bagian tanaman padi. Terdapat beberapa cara yang dapat digunakan untuk memberantas hama, salah satunya yaitu menggunakan pestisida berbahan kimia dan pestisida nabati, contohnya adalah mindi.
\end{abstract}

Kata Kunci: tanaman padi, hama, orthoptera

\section{PENDAHULUAN}

Indonesia adalah negara yang memiliki kekayaan alam yang melimpah, baik flora maupun faunanya (Najicha, 2021). Salah satu diantara kekayaan flora tersebut adalah tanaman padi. Pada umumnya, banyak masyarakat sudah tahu bahwa tanaman padi tersebut akan menghasilkan beras yang nantinya akan diolah menjadi nasi dan dijadikan sebagai sumber energi untuk tubuh manusia. Beras yang telah lama menjadi sumber makanan pokok sangat sulit untuk digantikan oleh bahan pokok lainnya seperti sagu, umbi-umbian, jagung, dan sumber karbohidrat lainnya. Menurut Donggulo (2017), keberadaan beras menjadi prioritas utama bagi masyarakat dalam memenuhi kebutuhan karbohidrat yang mengenyangkan, padi sebagai tanaman pangan dikonsumsi kurang lebihnya 90\% dari keseluruhan penduduk Indonesia untuk makanan pokok sehari-hari. Di Indonesia sendiri yang memiliki tanah yang subur dan luas, padi banyak ditanam di lahan luas yang biasanya disebut sawah.

Sebagai sesama makhluk hidup, sawah yang ditempati sebagai tempat tanaman padi tidak hanya dijadikan tempat pertumbuhan tanaman padi melainkan juga sebagai habitat beberapa fauna. Fauna yang hidup di sekitar tanaman padi tersebut dapat bersifat menguntungkan maupun merugikan bagi pertumbuhan tanaman padi. Fauna yang dapat merugikan pertumbuhan padi disebut dengan hama tumbuhan padi. Menurut Wati (2021), serangan fauna yang tergolong hama atau penyakit dapat ditemukan mulai dari pembibitan, fase awal tanam, fase vegetatif, fase generatif, fase menjelang, dan fase pasca panen, kemudian kehilangan hasil yang diakibatkan oleh serangan hama pada tanaman padi berkisar antara $24-41 \%$.

Terdapat banyak jenis hama yang hidup di sekitar tanaman padi, salah satunya berasal dari ordo Orthoptera. Beberapa spesies hama yang berasal dari ordo Orthoptera yaitu beberapa jenis belalang, jangkrik, dan orong-orong, namun tidak semua spesies ordo Orthoptera merupakan hama tumbuhan karena beberapa di antaranya merupakan omnivora (Famili Gryllidae dan Blattidae) dan predator (Famili Mantidae) sebagai musuh alami hama tumbuhan (Sari, Suartini, dan Muksin, 2018). Ordo Orthoptera merupakan serangga yang memiliki sayap namun ada juga yang tidak memiliki sayap. Spesies ordo Orthoptera yang memiliki sayap, pada umumnya memiliki empat buah sayap yang pada bagian depannya memanjang, banyak rangka-rangka sayap, serta menebal yang disebut tegmina (tegmen). Sayap bagian belakang berselaput tipis, lebar, dan banyak rangka-rangka sayap, serta pada waktu mereka beristirahat biasanya sayapnya terlipat seperti kipas di bawah sayap-sayap depan. Kemudian, spesies 
ordo Orthoptera memiliki kaki belakang yang lebih besar dan panjang daripada kaki depan dan kaki tengah. Kaki belakang tersebut berfungsi untuk meloncat, serta penghasil suara. Namun, terdapat beberapa spesies dari ordo Orthoptera yang menghasilkan suara menggunakan sayap depan (Mita, 2015). Ciri mata spesies ordo Orthoptera tunggal atau majemuk serta terdapat antena dengan ukuran sedang maupun panjang, tipe mulut menggigit dan mengalami metamorfosis yang tidak sempurna (Arsyad, 2021). Tujuan penelitian ini adalah untuk mendeskripsikan jenis-jenis hama tanaman padi dari ordo Orthoptera di Desa Mantingan, Kabupaten Ngawi. Setelah mengetahui karakteristik jenis hama tanaman padi yang ada di sawah Desa Mantingan, maka dapat dilakukan pencegahan tanpa menimbulkan dampak negatif terhadap lingkungan.

\section{METODE}

Penelitian ini dilaksanakan pada bulan September hingga November 2021 di Desa Mantingan, Kecamatan Mantingan, Kabupaten Ngawi, Jawa Timur. Penelitian ini diawali dengan pengambilan gambar di wilayah persawahan Desa Mantingan, lalu didapatkan beberapa spesies dari ordo Orthoptera. Kemudian penelitian dilanjutkan dengan mengidentifikasi setiap spesies yang telah ditemukan.

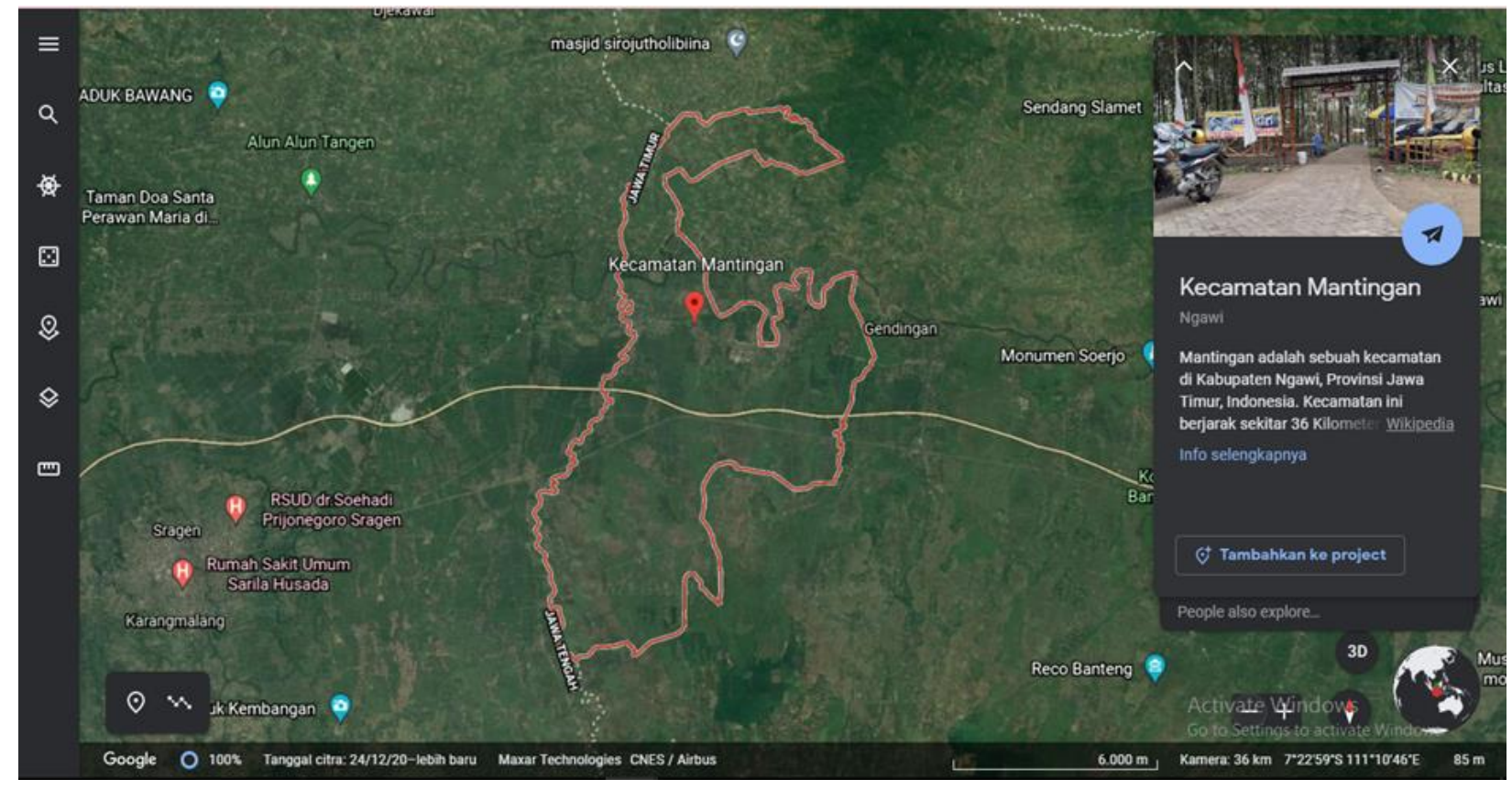

Gambar 1. Desa Mantingan, Kecamatan Mantingan, Kabupaten Ngawi

(Dimodifikasi dari Google Earth, 2021)

Penelitian ini menggunakan metode pengamatan secara langsung atau observasi dan studi literatur. Sampel yang akan digunakan yakni ordo Orthoptera di kawasan persawahan Desa Mantingan, Kecamatan Mantingan, Kabupaten Ngawi. Ordo Orthoptera yang ditemukan seperti belalang dan spesies lainnya dilanjutkan dengan dokumentasi untuk setiap spesies yang ditemukan. Pengambilan dokumentasi dari sampel yang ditemukan dilaksanakan pada pagi hari hingga siang hari. Studi literatur digunakan untuk mengidentifikasi taksonomi dan morfologi spesies yang ditemukan. Karakteristik morfologi dan identifikasi setiap spesies yang diidentifikasi melalui pengamatan kemudian akan mengacu pada studi literatur. Dalam pembuatan kunci determinasi akan didasarkan pada karakteristik dan identifikasi yang telah dilakukan.

Jenis dari Ordo Orthoptera yang didapatkan, dianalisis secara deskriptif dan diidentifikasi hingga tingkatan spesies, kemudian dibuat kunci determinasi yang berdasarkan hasil identifikasi dan studi literatur. Untuk mempermudah pembuatan kunci determinasi, maka dituliskan pada tabel untuk mempermudah analisis.

\section{HASIL DAN PEMBAHASAN}

Beberapa spesies hama tumbuhan padi yang ditemukan pada ekosistem sawah di Desa Mantingan, Kabupaten Ngawi sebanyak 3 spesies, yaitu diantaranya Oxya chinensis, Atractomorpha crenulata, dan Gryllotalpa hirsuta. Berikut penjabaran dari masing-masing spesies yang telah diamati. 


\section{Oxya chinensis}

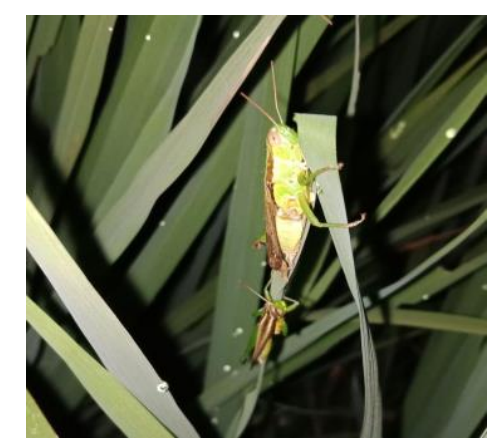

Gambar 2. Oxya chinensis

(Dokumentasi pribadi, 2021)

Kingdom : Animalia

Filum : Arthropoda

Kelas : Insecta

Ordo : Orthoptera

Famili : Acrididae

Genus : Oxya

Spesies : Oxya chinensis

(Syahrin, 2019).

Oxya chinensis atau biasa disebut belalang hijau memiliki warna dominan hijau pada tubuh dan kakinya, memiliki sayap luar yang berwarna kecoklatan dan bagian perut berwarna kekuningan. Menurut Borror (1992), belalang memiliki dua pasang sayap, yaitu sayap depan dan sayap belakang. Sayap depan lebih sempit daripada sayap belakang, sayap depan memiliki vena-vena yang menebal atau mengeras. Sayap belakang melebar dengan vena-vena yang teratur, dan ketika beristirahat sayap belakang akan melipat di bawah sayap depan. Belalang ini memiliki kepala berbentuk agak lonjong dengan sepasang antena di bagian kepala, memiliki sepasang mata yang menonjol. Belalang ini memiliki tipe mulut penggigit dan pengunyah. Memiliki 6 kaki, dimana empat kaki depan memiliki ukuran yang lebih kecil dan lebih pendek dari pada dua kaki belakang. Empat kaki depan berfungsi untuk berjalan, dan dua kaki belakang yang memiliki ukuran lebih panjang dan lebih besar berfungsi untuk meloncat tinggi.

Belalang hijau merupakan herbivora yang memakan dedaunan. Di sawah belalang ini sering dijumpai di tanaman padi dan memakan daun-daun dari tanaman padi. Menurut Yuliani (2016), Oxya sp adalah salah satu hama yang menyerang tanaman padi baik pada musim hujan maupun musim kemarau, dan salah satu hama pada tanaman padi yang dilaporkan menimbulkan kerugian yang cukup berarti. Oxya chinensis atau belalang hijau ini merupakan belalang yang hidup berkelompok, dan ketika memangsa tanaman padi belalang ini memangsa tanaman padi secara berkelompok dalam jumlah yang cukup banyak. Sehingga para banyak petani yang resah dengan belalang ini.

\section{Atractomorpha crenulata}

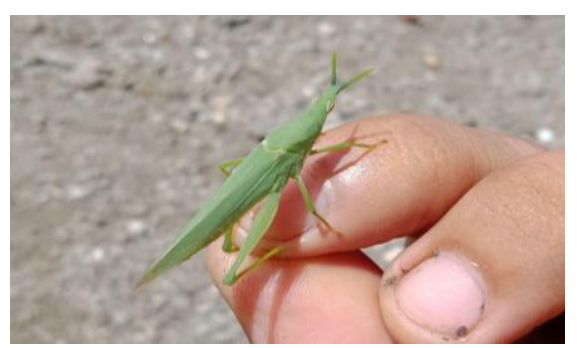

Gambar 3. Atractomorpha crenulata

(Dokumentasi pribadi, 2021) 


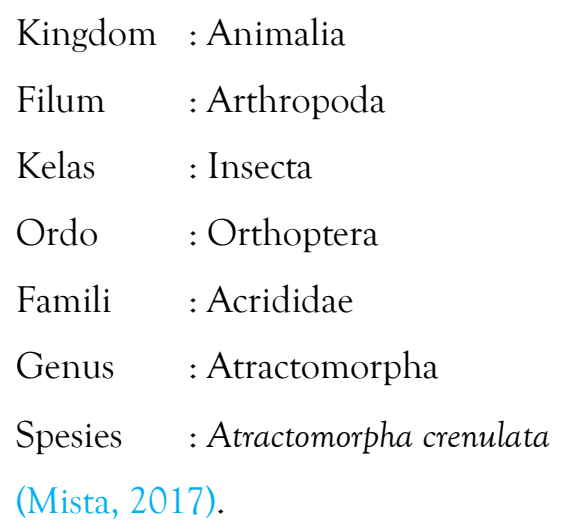

Atractomorpha crenulata atau biasa disebut belalang kukus hijau memiliki warna tubuh hijau. Bagian bawah perut berwarna agak keputihan. Menurut Borror (1992), belalang memiliki dua pasang sayap, yaitu sayap depan dan sayap belakang. Sayap depan lebih sempit daripada sayap belakang, sayap depan memiliki vena-vena yang menebal atau mengeras. Sayap belakang melebar dengan vena-vena yang teratur, dan ketika beristirahat sayap belakang akan melipat di bawah sayap depan. Belalang ini memiliki bentuk kepala mengerucut lancip di depan, dengan sepasang sungut pendek di ujung kepala. Belalang kukuh hijau memiliki sepasang mata agak menonjol di samping kepala. Belalang ini memiliki tipe mulut penggigit dan pengunyah. Memiliki 6 kaki, di mana empat kaki depan memiliki ukuran yang lebih kecil dan lebih pendek dari pada dua kaki belakang. Empat kaki depan berfungsi untuk berjalan, dan dua kaki belakang yang memiliki ukuran lebih panjang dan lebih besar berfungsi untuk meloncat. Belalang ini memakan dedaunan hijau pada tanaman yang ada di sawah, sehingga sering dianggap sebagai hama oleh para petani.

\section{Gryllotalpa hirsuta}

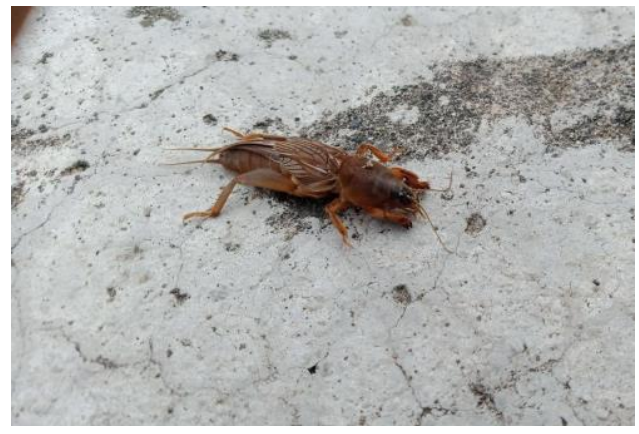

Gambar 3. Gryllotalpa hirsuta

(Dokumentasi pribadi, 2021)

Kingdom : Animalia

Filum : Arthropoda

Kelas : Insecta

Ordo : Orthoptera

Famili : Gryllotalpidae

Genus : Gryllotalpa

Spesies : Gryllotalpa hirsute

(Cahyono, Ahmad, dan Tolangara, 2018)

Gryllotalpa hirsuta atau sering disebut anjing tanah, di beberapa daerah disebut juga orong-orong memiliki warna tubuh coklat kehitaman. Orong-orong hidup di dalam tanah. Hewan ini termasuk hewan yang aktif di malam hari atau disebut hewan nokturnal. Orong-orong memiliki kepala yang keras, memiliki sepasang mata yang agak menonjol, dan memiliki sepasang sungut pendek di ujung kepalanya. Orong-orong memiliki sayap di bagian atas tubuhnya yang digunakan untuk terbang. Bentuk sayapnya memiliki vena-vena yang teratur. Hewan ini memiliki enam kaki, dimana empat kaki belakang digunakan untuk berjalan. Dan dua kaki depan 
termodifikasi memiliki bentuk besar dan keras berfungsi seperti cangkul untuk menggali tanah. Dua kaki depan orong-orong ini termasuk tipe fussorial, yaitu tungkai yang digunakan untuk menggali, ditandai dengan adanya kuku depan yang keras (Jumar, 2000).

Menurut Solikhin dan Purnomo (2020), Orong-orong adalah hama yang dapat merusak tanaman pada berbagai fase tumbuh. Orong-orong mulai menyerang tanaman padi pada saat padi sudah mulai tumbuh. Hewan ini memakan pangkal pohon dan akar pada tanaman padi, pertanaman padi yang masih muda jika terserang hama ini biasanya akan terlihat adanya spot atau daerah yang kosong. Orong-orong menyerang tanaman padi pada malam hari, dan akan terlihat banyak ketika masa awal penanaman padi. Pada saat sudah panen orongorong biasanya akan susah ditemui di persawahan. Namun, ketika pengolahan tanah sawah dengan bajak, orongorong terlihat berenang-renang untuk menyelamatkan diri ke tempat yang tidak tergenang air.

Tabel 1. Daftar Temuan Hama Serangga Pada Ekosistem Sawah di Desa Mantingan

\begin{tabular}{cccccc}
\hline No & Nama Lokal & Ordo & Famili & Genus & Spesies \\
\hline 1 & Belalang hijau & Orthoptera & Acrididae & Oxya & Oxya chinensis \\
2 & Belalang kukus hijau & Orthoptera & Acrididae & Atractomorpha & $\begin{array}{c}\text { Atractomorpha crenulata } \\
\text { Gryllotalpa hirsuta }\end{array}$ \\
\hline
\end{tabular}

(Data pribadi, 2021)

Berdasarkan hasil penelitian yang dipaparkan pada tabel 1, telah dilakukan di kawasan persawahan di Desa Mantingan, Kabupaten Ngawi dan ditemukan sebanyak tiga spesies hama dari ordo Orthoptera, yaitu Oxya chinensis, Atractomorpha crenulata, dan Gryllotalpa hirsuta. Spesies yang telah ditemukan paling banyak berasal dari famili Acrididae.

Kondisi lingkungan yang mempengaruhi adanya tiga spesies tersebut diantaranya dipengaruhi oleh suhu yaitu $25-31^{\circ} \mathrm{C}$. Menurut Jumar dalam tulisan milik Kumalararas (2018), serangga dapat beraktivitas secara efektif apabila suhu berkisar antara $15-25^{\circ} \mathrm{C}$. Maksimum suhu yang dapat ditoleransi sebesar $45^{\circ} \mathrm{C}$. Selain itu, spesies yang ditemukan di lokasi, dipengaruhi oleh adanya tumbuhan sebagai sumber makanan. Banyaknya tanaman padi di Desa Mantingan akan mendukung kehidupan spesies tersebut.

Serangga herbivora termasuk ketiga spesies yang ditemukan merupakan serangga hama yang dapat menimbulkan kerugian secara ekonomi bagi para petani karena memakan tumbuh-tumbuhan, salah satunya padi. Menurut Sari (2018), kualitas tanaman padi dapat mempengaruhi distribusi hama dan kelimpahannya serta menjadi makanan bagi hama herbivora. Banyaknya spesies Orthoptera yang ditemukan di Desa Mantingan dikarenakan melimpahnya tanaman padi yang menjadi makanan bagi serangga herbivora.

Berdasarkan morfologi dari setiap spesies, berikut adalah tabel kunci determinasi spesies hama tanaman padi dari ordo Orthoptera pada ekosistem sawah di Desa Mantingan, Kabupaten Ngawi.

Tabel 2. Kunci Determinasi Spesies Hama Tanaman Padi dari Ordo Orthoptera pada Ekosistem Sawah di Desa Mantingan

1a. Warna tubuh dominan hijau .....

1b. Warna tubuh dominan cokelat.

2a. Menyerang daun hijau tanaman padi

2b. Menyerang pangkal batang dan akar tanaman padi. Gryllotalpa hirsuta

3a. Bentuk kepala bulat lonjong.. Oxya chinensis

3b. Bentuk kepala lancip Atractomorpha crenulata

(Data pribadi, 2021).

Sebab adanya hama dapat mengganggu aktivitas pertumbuhan suatu tanaman termasuk padi dan menimbulkan dampak kerugian ekonomi para petani, maka hama tanaman padi harus diberantas. Cara memberantas hama yang biasa digunakan oleh para petani yaitu menggunakan pestisida kimia. Namun, penggunaan pestisida kimia dapat menyebabkan masalah pencemaran lingkungan dikarenakan residu 
penyemprotan pestisida terhadap tanaman tidak cepat hilang dan dapat mencapai waktu hampir seminggu (Wedastra, 2020).

Selain penggunaan pestisida kimia, terdapat bahan lain yang dapat digunakan untuk memberantas hama tanaman padi, yaitu pestisida nabati. Pestisida nabati adalah pestisida alami yang bahan dasarnya didapatkan dari tumbuh-tumbuhan, seperti akar, batang, daun, dan buahnya. Pestisida nabati relatif lebih mudah dibuat dan bahannya mudah didapat. Karena bahannya alami, pestisida ini bersifat mudah terurai dan tidak mencemari lingkungan, sehingga relatif lebih aman. Bahan alami yang dapat digunakan salah satunya yaitu mindi yang dapat memberantas hama jenis kutu daun, hama daun, anjing tanah, belalang, wereng, dan ulat grayak (Ratnasari, 2017).

\section{SIMPULAN}

Berdasarkan hasil pengamatan serangga hama dari ordo Orthoptera pada ekosistem sawah di Desa Mantingan, Kabupaten Ngawi, ditemukan tiga spesies hama, diantaranya Oxya chinensis (belalang hijau), Gryllotalpa hirsuta (anjing tanah atau orong-orong), dan Atractomorpha crenulata (belalang kukus hijau). Ketiga hama tersebut menyerang tanaman padi dengan cara menggigit dan mengunyah pada bagian tanaman padi. Maka dari itu, terdapat beberapa cara yang dapat digunakan untuk memberantas hama, salah satunya yaitu menggunakan pestisida berbahan kimia dan pestisida nabati, contohnya adalah mindi.

Saran yang diajukan oleh peneliti adalah hendaknya pada penelitian selanjutnya dapat mempersiapkan kembali mengenai faktor-faktor kebutuhan apa saja yang dibutuhkan untuk mengamati hama serangga tanaman padi di sawah.

\section{Ucapan Terima Kasih}

Terima kasih penulis ucapkan kepada keluarga yang selalu mendukung, dosen pengampu mata kuliah Biodiversitas yang telah memberikan arahan, dan kepada teman sekelompok yang telah berpartisipasi dengan baik dalam pembuatan artikel ini. Tidak hanya itu, penulis juga mengucapkan terima kasih kepada responden serta teman-teman yang telah membantu dalam penelitian ini, serta seluruh pihak yang telah membantu dan mempermudah urusan penulis sehingga penulis bisa menyelesaikan penelitian ini hingga akhir.

\section{Daftar Pustaka}

Arsyad, Muhammad. 2021. Biologi Umum. Bogor: Guepedia.

Borror, D. J., N. F. Johnson, and C. A. Triplehorn. 1992. Pengenalan Pelajaran Serangga. edited by Suryobroto. Yogyakarta: UGM Press.

Cahyono, Didi Budi, Hasna Ahmad, and A. R. Tolangara. 2018. "Hama Pada Cabai Merah.” Techno: Jurnal Penelitian 6(02):18. doi: 10.33387/tk.v6i02.565.

Donggulo, Candra V., Iskandar Lapanjang, and Usman Made. 2017. "Pertumbuhan Dan Hasil Tanaman Padi (Oryza Sativa L.) Pada Berbagai Pola Jajar Legowo Dan Jarak Tanam.” Jurnal Agroland 4(1):35-37.

Jumar. 2000. Entomologi Pertanian. Jakarta: PT Rineka Cipta.

Kumalararas, Ratih. 2018. "Keanekaragaman Jenis Belalang (Orthoptera: Caelifera) Di Zona Rehabilitasi Resort Wonoasri Taman Nasional Meru Betiri.” Universitas Negeri Jember.

Mista. 2017. "Keanekaragaman Serangga (Insecta) Pada Sekitar Perkebunan Cabai Merah (Capsicum Annum L.) Di Desa Lubuk Lancang Dan Pengajarannya Di SMA 9 Palembang.” Universitas Muhammadiyah Palembang.

Mita, Diah Prajana. 2015. "Inventarisasi Ordo Orthoptera Di Kawasan Taman Nasional Alas Purwo (TNAP) Banyuwangi Jawa Timur.” UNiversitas Negeri Jember.

Najicha, fatma Ulfatun. 2021. "Dampak Kebijakan Alih Fungsi Kawasan Hutan Lindung Menjadi 
Areal Pertambangan Berakibat Pada Degradasi Hutan.” Proceeding of Conference on Law and Social Studies (28): 11.

Ratnasari, Dewi. 2017. "Mengendalikan Hama Dan Penyakit Secara Alami."

Sari, I. Gusti Putu Diah Purnama, Ni Made Suartini, and I. Ketu Muksin. 2018. "Inventarisasi JenisJenis Serangga Ordo Orthoptera Pada Tanaman Jagung Di Desa Kesiman-Denpasar.” Jurnal Simbiosis 4(1).

Solikhin, and Purnomo. 2020. "Populasi Orong-Orong (Gryllotalpa Spp.) Dan Kerusakan Tanaman Padi Musim Tanam Gadu Di Punggur, Lampung Tengah.” Jurnal Agrotek Tropika 8(2):401-7.

Syahrin, Fajrin Alfi. 2019. "Keanekaragaman Ordo Orthoptera (Belalang) Di Kawasan Situs Gunung Padang Cianjur Jawa Barat Sebagai Bahan Ajar SMA.” Universitas Pasundan.

Wati, Cheppy, and dkk. 2021. Hama Dan Penyakit Tanaman. Medan: Yayasan Kita Menulis.

Wedastra, Made Suma, I. Dewa Gede Suartha, Theresia Suzanna Catharina, Ida Ayu Ketut Marini, Ni Wayan Putu Meikapasa, and Ida Ayu Nopiari. 2020. "Pengendalian Hama Penyakit Terpadu Untuk Mengurangi Kerusakan Pada Tanaman Padi Di Desa Mekar Sari Kecamatan Gunung Sari." Jurnal Gema Ngabdi 2(1):88-94. doi: 10.29303/jgn.v2i1.68.

Yuliani, Dini, Khairatun Napisah, and Nina Maryana. 2016. "Status Oxya Spp. (Orthoptera: Acrididae), Sebagai Hama Pada Pertanaman Padi Dan Talas Di Daerah Bogor.” Jurnal Inovasi Teknologi Pertanian. 